\title{
Multiple effects of Xihuang pill aqueous extract on the Hs578T triple-negative breast cancer cell line
}

\author{
WENXIAN ZHENG ${ }^{1,2}$, SHUYAN HAN $^{1,2}$, SHANTONG JIANG ${ }^{1,2}$, LINA PANG $^{1,2}$, \\ XIAOHONG LI ${ }^{1,2}$, XIJUAN LIU ${ }^{3}$, MINHUA CAO $^{3}$ and PINGPING LI ${ }^{1,2}$ \\ ${ }^{1}$ Key Laboratory of Carcinogenesis and Translational Research, Ministry of Education, Peking University \\ Cancer Hospital and Institute; ${ }^{2}$ Department of Integration of Chinese and Western Medicine, Peking University \\ School of Oncology; ${ }^{3}$ Central Laboratory, Key Laboratory of Carcinogenesis and Translational Research, \\ Ministry of Education, Peking University Cancer Hospital and Institute, Beijing 100142, P.R. China
}

Received May 14, 2016; Accepted August 23, 2016

DOI: $10.3892 /$ br.2016.769

\begin{abstract}
The management of triple-negative breast cancer (TNBC) is challenging due to the aggressive behavior, lack of therapeutic options and relatively poor prognosis. Xihuang pill (XHP) is a well-known Traditional Chinese Medicine with anticancer activity. The aim of the present study was to investigate whether the aqueous extract of XHP (AEXHP) has anti-proliferative activity against the Hs578T TNBC cell line, and to elucidate its molecular mechanisms of action. First, an MTT assay was used to evaluate the anti-proliferative activity of AEXHP on the Hs578T cell line; furthermore, the cell cycle distribution, mitochondrial membrane potential and apoptotic rate were determined by flow cytometry, and western blot analysis was used to assess the expression of apoptosis and cell cycle regulatory proteins to investigate the mechanisms of action. The results revealed that the cell viability was significantly inhibited by AEXHP in a dose- and time-dependent manner. Apoptosis and mitochondrial membrane potential loss were detected, and after treatment with 4, 8 and $12 \mathrm{mg} / \mathrm{ml}$ AEXHP for $24 \mathrm{~h}$, cleaved caspase-3 was 1.70-, 1.81- and 1.84-fold of that of the control, while procaspase-3, procaspase-8, cleaved caspase-8, B-cell lymphoma 2 (Bcl-2), Bcl-2-associated X protein (Bax) and the Bcl-2/Bax ratio were not significantly affected. Cell cycle analysis revealed that treatment with AEXHP led to S-phase arrest of Hs578T cells. Furthermore, AEXHP treatment resulted in decreased expression of cyclin $\mathrm{A}$ and cyclin dependent kinase 2 (CDK2), and increased expression
\end{abstract}

Correspondence to: Professor Pingping Li, Key Laboratory of Carcinogenesis and Translational Research, Ministry of Education, Peking University Cancer Hospital and Institute, 52 Fucheng Road, Beijing 100142, P.R. China

E-mail:1ppma123@sina.com

Key words: Xihuang pill, aqueous extract, anti-proliferative activity, apoptosis, cell cycle, Hs578T, triple-negative breast cancer of cyclin E and p21 Cip1, as compared to the control group. In conclusion, the viability of Hs578T cells was significantly inhibited by AEXHP in a dose- and time-dependent manner, the likely mechanisms of which being induction of apoptosis, probably via the intrinsic, Bcl-2-independent pathway, and cell cycle arrest in $\mathrm{S}$ phase due to decreased expression of cyclin $\mathrm{A}$ and CDK2, and increased expression of cyclin E and p21 $1^{\mathrm{Cip} 1}$.

\section{Introduction}

Breast cancer is the second most common type of cancer worldwide and the most common cancer type in women. Triple-negative breast cancer (TNBC), accounting for $10-15 \%$ (1) of all breast cancer cases, is characterized by the absence of progesterone and estrogen receptor as well as human epidermal growth factor receptor-2 (2). Management of TNBC is challenging due to its aggressive behavior, lack of targeted therapies and relatively poor prognosis (3). At present, only few therapeutic options are available, and conventional chemotherapy is the only effective adjuvant treatment for TNBC patients after surgery (4), which, however, has severe side effects. Therefore, it is important to discover novel therapeutic agents with low toxicity for TNBC treatment. Traditional Chinese Medicine has been used for cancer treatment for a long time either alone or in combination with western medicines (5). It is a promising field providing numerous sources of anticancer agents, which deserve further investigation for being developed into novel clinical treatments.

Xihuang pill (XHP) is a well-known Chinese medicine formula first mentioned in in a document from 1740 in the Qing dynasty period of China (6). XHP contains Niuhuang (Bos Taurus domesticus Gmelin), Shexiang (Moschusmoschiferus Linnaeus), Ruxiang (Boswellia carterii Birdw) and Moyao (Commiphora myrrha Engl.). Its main uses are detoxification as well as relief of swelling and pain. XHP is mainly used for the treatment of furunculosis, scrofula and neoplasms. In the clinical practice, the anticancer activities of XHP have been documented for malignancies including breast and liver cancer as well as leukemia (7). While evidence for the antitumor effects of XHP against TNBC is rare, a recent study by Pan et al (8) was the first to assess the effects of aqueous 
extract of XHP (AEXHP) on a TNBC cell line, MDA-MB-231, revealing a cytotoxic effect, the possible mechanism of which was indicated to be associated with induction of apoptosis; however, the molecular mechanisms were not further investigated. The aim of the present study was to investigate the effects of AEXHP on another TNBC cell line, namely Hs578T, with the aim of assessing its anti-proliferative activity and the underlying molecular mechanisms. To the best of our knowledge, the present study was the first to demonstrate that the cytotoxic effects of AEXHP in TNBCs may be associated with induction of cell cycle arrest.

\section{Materials and methods}

Chemicals and antibodies. XHP was purchased from Tong Ren Tang Technologies Co., Ltd. (Beijing, China). Dimethyl sulfoxide (DMSO) and 3-(4,5-dimethyl-2-thiazolyl)-2, 5-diphenyl-2-H-tetrazolium bromide (MTT) were purchased from Sigma-Aldrich (St. Louis, MO, USA). Caspase-3 monoclonal antibody (cat. no. ab32351; 1:3,000 dilution) was purchased from Abcam (Cambridge, UK). Cyclin dependent kinase 2 (CDK2) (cat. no. 2546; 1:5,000 dilution), cyclin A (cat. no. 4656; 1:5,000 dilution), cyclin E (cat. no. 4129; 1:5,000 dilution), p21 ${ }^{\text {Cip1 }}$ (cat. no. 2947; 1:5,000 dilution), caspase-8 (cat. no. 9746; 1:4,000 dilution), B-cell lymphoma 2 (Bcl-2; cat. no. 2870; 1:5,000 dilution) and Bcl-2-associated $\mathrm{X}$ protein (Bax; ca. no. 5023; 1:5,000 dilution) monoclonal antibodies were purchased from Cell Signaling Technology (Beverly, MA, USA). $\beta$-actin rabbit monoclonal antibody (cat. no. TDY051; 1:5,000 dilution) was purchased from TDYbio (Beijing, China). Peroxidase-conjugated goat anti-rabbit immunoglobulin (Ig) G (cat. no. ZB-2306) and goat anti-mouse IgG (cat. no. ZF-0312; both 1:5,000 dilution) were purchased from the Zhongshang Goldenbridge-BIO (Beijing, China).

Extract preparation. XHP (3 g) was immersed in $15 \mathrm{ml}$ cold distilled water and stirred for $2 \mathrm{~h}$ at $4^{\circ} \mathrm{C}$. Subsequently, XHP was extracted for $2 \mathrm{~h}$ at $37^{\circ} \mathrm{C}$ in an ultrasound oscillator and centrifuged at $1,500 \mathrm{x} \mathrm{g}$ for $5 \mathrm{~min}$ at $4^{\circ} \mathrm{C}$. The supernatant was centrifuged again at $4,800 \mathrm{x}$ g for $15 \mathrm{~min}$ at $4^{\circ} \mathrm{C}$, and the final supernatant was filtered through a sterile microporous membrane $(0.45 \mu \mathrm{m})$ and stored at $-20^{\circ} \mathrm{C}$. For treatment of the cells, AEXHP was diluted with Dulbecco's modified Eagle's medium (DMEM) to the desired concentrations.

Cell culture. The Hs578T human TNBC cell line was obtained from the cell bank of Chinese Academy of Medical Sciences (Shanghai, China). The cells were cultured in DMEM (Gibco, Thermo Fisher Scientific, Inc., Waltham, MA, USA) with $10 \%$ fetal bovine serum (Hyclone, Logan, UT, USA) and antibiotics (100 U/ml penicillin and $100 \mu \mathrm{g} / \mathrm{ml}$ streptomycin).

The MCF-10A human breast epithelial cell line also obtained from the cell bank of Chinese Academy of Medical Sciences. The cells were grown, maintained and treated in medium containing DMEM/F-12 (Gibco) 1:1 mix, supplemented with human insulin $(10 \mu \mathrm{g} / \mathrm{ml})$, epidermal growth factor $(20 \mathrm{ng} / \mathrm{ml})$, cholera toxin $(100 \mathrm{ng} / \mathrm{ml})$, hydrocortisone $(0.5 \mu \mathrm{g} / \mathrm{ml}), 5 \%$ horse serum (Hyclone) and antibiotics (100 U/ml penicillin and $100 \mu \mathrm{g} / \mathrm{ml}$ streptomycin).
The cell lines were incubated in a humidified atmosphere containing $5 \% \mathrm{CO}_{2}$ at $37^{\circ} \mathrm{C}$.

MTT assay. Cells $\left(7.5 \times 10^{3}\right.$ or $1 \times 10^{4} /$ well $)$ were seeded in 96-well plates (Corning Inc., Corning, NY, USA) and treated on the following day with various concentrations of AEXHP $(0,4,8,12$ or $16 \mathrm{mg} / \mathrm{ml})$ for 12,24 or $48 \mathrm{~h}$ [the units 'weight per volume' refer to the quantity of solid XHP and the volume of water used for extraction, which was performed according to a previously published procedure (8)]. Subsequently, the cells were subjected to an MTT assay (9) and the optical density (OD) was determined at $570 \mathrm{~nm}$ using a 96-well microplate reader (Applied Biosystems; Thermo Fisher Scientific, Inc.). Since reduction of MTT only occurred in metabolically active cells, the OD was a measure of the viability of the cells. The viability rate was calculated according to the following formula: $\mathrm{OD}_{\text {treatment }} / \mathrm{OD}_{\text {control }} \times 100 \%$.

Apoptosis assay. Hs578T Cells $\left(2.4 \times 10^{5}\right)$ were seeded in a 30-mm culture dish (Corning Inc.). On the following day, cells were treated with AEXHP (0, 4, 8 or $12 \mathrm{mg} / \mathrm{ml})$. After $24 \mathrm{~h}$ of incubation, cells were trypsinized, washed with cold phosphate-buffered saline (PBS) and stained using an annexin V/FITC kit (BestBio, Shanghai, China). The cells were then analyzed on a FACSCalibur flow cytometer (Becton Dickinson, Franklin Lakes, NJ, USA).

Mitochondrial membrane potential $\left(\Delta \psi_{m}\right)$ assay. $\Delta \psi_{\mathrm{m}}$ loss was detected using a mitochondrial membrane potential assay kit (Beyotime Institute of Biotechnology, Haimen, China). In brief, Hs578T cells $\left(2.4 \times 10^{5}\right)$ were seeded into a $30-\mathrm{mm}$ culture dish. On the following day, the cells were treated with $\operatorname{AEXHP}(0,4,8$ or $12 \mathrm{mg} / \mathrm{ml})$. After $24 \mathrm{~h}$ of incubation, the cells were trypsinized and incubated with $\mathrm{JC}-1$ at $37^{\circ} \mathrm{C}$ for $15 \mathrm{~min}$. Subsequent to washing with JC-1 staining buffer twice, the cells were immediately analyzed by flow cytometry.

Cell cycle distribution assay. Hs $578 \mathrm{~T}$ cells $\left(6 \times 10^{5}\right)$ were seeded in a 50-mm culture dish. On the following day, the cells were treated with AEXHP $(0,4,8$ or $12 \mathrm{mg} / \mathrm{ml})$ for $48 \mathrm{~h}$. Subsequent to trypsinization and washing with PBS, cells were fixed in $1 \mathrm{ml}$ ice-cold $70 \%$ ethanol overnight at $4^{\circ} \mathrm{C}$. The cells were centrifuged $\left(1,000 \times \mathrm{g}, 5 \mathrm{~min}, 4^{\circ} \mathrm{C}\right)$, washed with cold PBS and treated with propidium iodide (PI)/RNase Staining Buffer (BD Pharmingen, San Diego, CA, USA) for $15 \mathrm{~min}$ at room temperature in the dark. The cell cycle distribution was then determined by flow cytometry. The percentage of cells in $\mathrm{G}_{1}$, $\mathrm{S}$ and $\mathrm{G}_{2} / \mathrm{M}$ phase was calculated using ModFit software $\mathrm{v} 3.2$ (Becton Dickinson, San Diego, CA, USA).

Western blot analysis. Hs578T cells $\left(2.25 \times 10^{6}\right)$ were seeded in a $100-\mathrm{mm}$ culture dish. On the following day, the cells were treated with $0,4,8$ or $12 \mathrm{mg} / \mathrm{ml}$ AEXHP. Following incubation for 24 or $48 \mathrm{~h}$, the cells were harvested, washed with cold PBS and homogenized with radioimmunoprecipitation assay lysis buffer (TDYbio). Total protein was extracted and the protein concentration was determined using a BCA protein assay kit (Thermo Fisher Scientific, Inc.). Subsequently, the proteins were mixed with $5 \mathrm{X}$ loading buffer (CWBIO, Beijing, China) and boiled for 
A
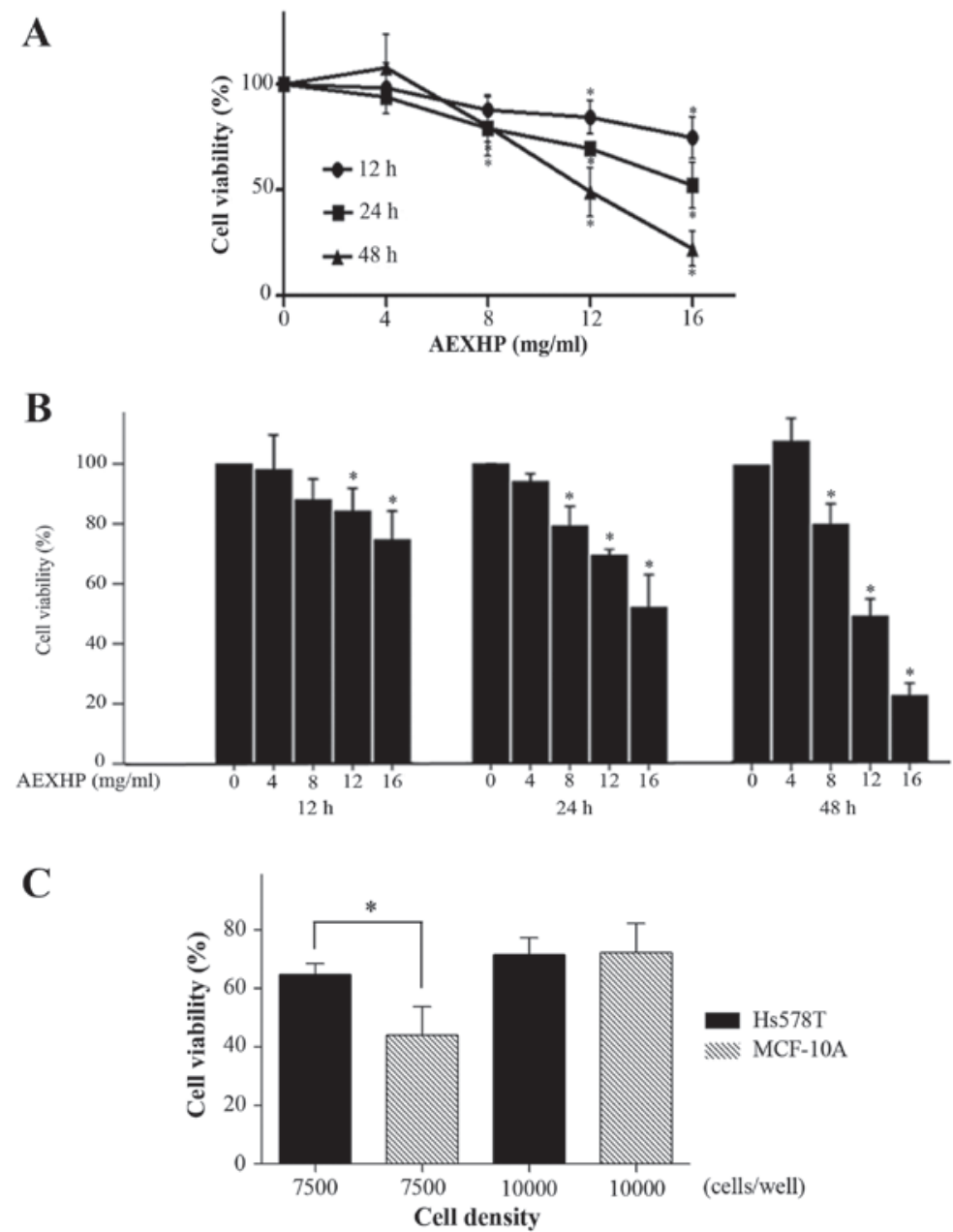

Figure 1. AEXHP reduces the viability of Hs578T cells. Hs578T cells (7,500/well) were treated with various concentrations of AEXHP $(0,4,8,12 \mathrm{or} 16 \mathrm{mg} / \mathrm{ml})$ for 12, 24 or $48 \mathrm{~h}$. (A) AEXHP decreased the cell viability in a dose-dependent manner. (B) AEXHP decreased the cell viability in a time-dependent manner. (C) The Hs578T cell line was not more sensitive to AEXHP than the MCF-10A normal breast cell line. Hs578T and MCF-10A were treated with $12 \mathrm{mg} / \mathrm{ml}$ XHP for $24 \mathrm{~h}$ and the cell viability was compared between the two cell lines at different cell densities. Values are expressed as the mean \pm standard deviation $(\mathrm{n}=3) .{ }^{*} \mathrm{P}<0.05$ vs. control. AEXHP, aqueous extract of Xihuang pill.

$5 \mathrm{~min}$. Samples of $35 \mu \mathrm{g}$ protein were separated by $10 \%$ sodium dodecyl sulfate-polyacrylamide gel electrophoresis, and transferred onto polyvinylidene difluoride membranes (Millipore, Billerica, MA, USA). Membranes were blocked for $2 \mathrm{~h}$ at room temperature with 5\% fat-free milk (YiLi Inc., Huhehaote, China) or 5\% bovine serum albumin (Amresco, Inc., Framingham, MA, USA) in $10 \mathrm{mM}$ Tris- $\mathrm{HCl}, 0.1 \mathrm{M}$ $\mathrm{NaCl}$ and $0.1 \%$ Tween-20, pH7.4 (TBST), and incubated with specific primary antibodies at $4^{\circ} \mathrm{C}$ overnight with gentle agitation. The membranes were washed with cold TBST and incubated with peroxidase-conjugated secondary antibody for $1 \mathrm{~h}$. Visualization of the protein bands was accomplished using an Immobilon Western Chemiluminescent HRP Substrate (Millipore). The intensity of protein bands was measured using ImageJ software 1.48 (National Institutes of Health, Bethesda, MD, USA), normalized to that of $\beta$-actin and presented as a percentage of the control.

Statistical analysis. Values are expressed as the mean \pm standard deviation of at least three independent experiments. Statistical analyses were performed using the two-tailed Student's t-test with SPSS 13.0 (SPSS, Inc., Chicago, IL, USA).
$\mathrm{P}<0.05$ was considered to indicate a statistically significant difference.

\section{Results}

AEXHP reduces the viability of $H$ s578T cells. To evaluate the cytotoxic effects of AEXHP on Hs578T cells, the viability of cells $\left(7.5 \times 10^{3} /\right.$ well) treated with various concentrations of AEXHP $(0-16 \mathrm{mg} / \mathrm{ml})$ was determined using an MTT assay. The results showed that AEXHP decreased the number of viable cells in a dose- and time-dependent manner (Fig. 1A and B). The inhibition of Hs578T cell viability by AEXHP started relatively early at $12 \mathrm{~h}$. At the highest concentration used $(16 \mathrm{mg} / \mathrm{ml})$, incubation with AEXHP for 12,24 or $48 \mathrm{~h}$ significantly decreased the cell viability rate to $74.67 \pm 9.63,52.07 \pm 10.89$ and $22.21 \pm 8.30 \%$, respectively, while there was no statistical difference between the control and the treatment group at the lowest concentration $(4 \mathrm{mg} / \mathrm{ml})$ at each time-point.

In order to investigate the difference in cytotoxicity/anti-proliferative effects of AEXHP on MCF-10A normal breast epithelial cells and Hs578T cells, each cell line was treated with $12 \mathrm{mg} / \mathrm{ml}$ AEXHP for $24 \mathrm{~h}$. At a seeding 
A

A AeXhP $0 \mathrm{mg} / \mathrm{ml}$

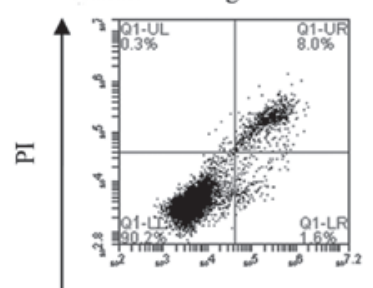

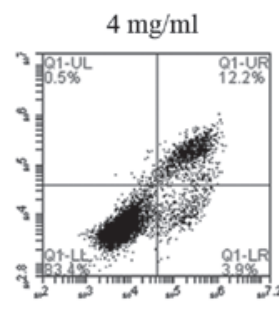
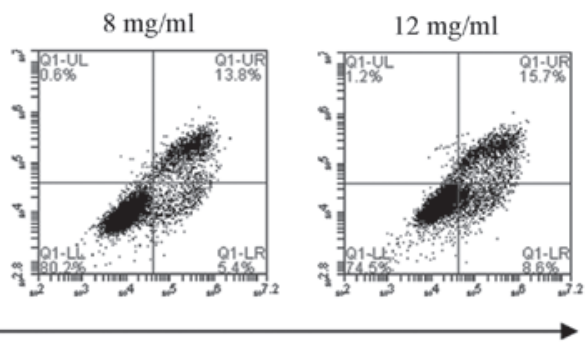

Annexin V-FITC

B

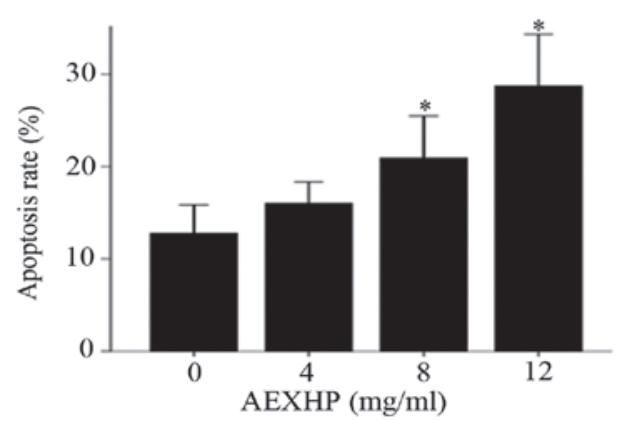

Figure 2. AEXHP induces apoptosis in Hs578T cells. (A) Apoptosis was determined by flow cytometry (dot plot representative of three experiments is shown). Cells were treated with AEXHP $(0,4,8$ or $12 \mathrm{mg} / \mathrm{ml})$ for $24 \mathrm{~h}$. (B) The apoptotic rate was calculated from the early (LR) plus late apoptotic (UR) rate. AEXHP induced apoptosis of Hs578T in a dose-dependent manner. Values are expressed as the mean \pm standard deviation ( $\mathrm{n}=3$ ). ${ }^{*} \mathrm{P}<0.05 \mathrm{vs}$. control. AEXHP, aqueous extract of Xihuang pill; PI, propidium iodide; FITC, fluorescein isothiocyanate; Q, quadrant; UL, upper left; LR, lower right.

density of 7,500 cells/well, the cell viability rate of Hs578T and MCF-10A decreased to $64.75 \pm 3.82$ and $43.93 \pm 9.96 \%$, respectively (Fig. 1C). There was a significant difference in the viability rate between these two cell lines $(\mathrm{P}<0.05)$. However, when the cell density was increased to 10,000 cells/well, the decreases in cell viability were similar between Hs578T and MCF-10A cells $(71.67 \pm 10.60$ and $72.41 \pm 9.80 \%$, respectively, vs. control) (Fig. 1C).

AEXHP induces apoptosis in Hs578T cells. In order to assess whether the anti-proliferative effects of AEXHP on Hs578T cells were due to induction of apoptosis, annexin V/PI double staining and flow cytometric analysis were used. After treatment with AEXHP (4, 8 or $12 \mathrm{mg} / \mathrm{ml})$ for $24 \mathrm{~h}$, the percentage of early apoptotic cells increased from $1.6 \%$ in the control group to $3.9,5.4$ and $8.6 \%$, respectively, and the percentage of cells in late apoptosis increased from $8.0 \%$ in the control group to $12.2,13.8$ and $15.7 \%$, respectively (Fig. 2A). At 8 and $12 \mathrm{mg} / \mathrm{ml}$, AEXHP significantly increased the overall apoptotic rate. In conclusion, AEXHP induced apoptosis in Hs578T cells in a dose-dependent manner (Fig. 2B).

AEXHP treatment leads to depletion of the $\Delta \psi_{m}$ in Hs578T cells. To assess whether the apoptosis of Hs578T cells was associated with the depletion of the $\Delta \psi_{\mathrm{m}}$, Hs578T treated with various concentrations of AEXHP were assessed by JC-1 staining and flow cytometric analysis. After treatment with AEXHP (4, 8 and $12 \mathrm{mg} / \mathrm{ml}$ ) for $24 \mathrm{~h}$, the percentage of cells with $\Delta \psi_{\mathrm{m}}$ loss increased from $4.5 \%$ in the control group to $11.8,14.4$ and $19.6 \%$, respectively, which was significant at the highest concentration $(\mathrm{P}<0.05)$ (Fig. 3A and $\mathrm{B})$. Thus, AEXHP induced the depletion of the $\Delta \psi_{\mathrm{m}}$ in Hs578T cells in a dose-dependent manner.
AEXHP induces apoptosis via the intrinsic pathway. Apoptosis may proceed via two major pathways, namely the intrinsic and the extrinsic pathway (10), each of them leading to caspase-3 activation. The caspase family is the most prominent protease family in apoptosis (11), and is divided into two functional groups, namely the apoptosis initiators (caspase-8, -9 and -10) and the apoptosis executors (caspase-3, -6 and -7) (12).

Bax is a well-known pro-apoptotic protein, while $\mathrm{Bcl}-2$ is an anti-apoptotic protein, and the $\mathrm{Bcl}-2 / \mathrm{Bax}$ ratio has a decisive role regarding the induction of apoptosis $(13,14)$. To determine whether caspase-3, caspase-8, Bax and Bcl-2 proteins were involved in apoptosis of Hs578T cells induced by AEXHP, the levels of these proteins were assessed by western blot analysis. The results showed that after treatment with AEXHP (4, 8 and $12 \mathrm{mg} / \mathrm{ml}$ ) for $24 \mathrm{~h}$, levels of cleaved caspase-3 were increased to 1.70-, 1.81- and 1.84-fold of that of the control $(\mathrm{P}<0.05)$, while no significant impact on the levels of procaspase-3, cleaved caspase-8, procaspase-8, Bcl-2, Bax, and the Bcl-2/Bax ratio was observed (Fig. 4A and B). In conclusion, the results indicated that AEXHP induces apoptosis via the intrinsic pathway, but not the extrinsic pathway, as only an involvement of caspase- 3 cleavage but no association with caspase-8, and Bcl-2/Bax ratio was found.

AEXHP induces cell cycle arrest in $S$ phase. Cell cycle regulation is important for cell proliferation, and induction of cell cycle arrest is the major mechanism via which numerous anti-tumor drugs exert their anti-proliferative effects $(15,16)$. To examine whether the anti-proliferative effects of AEXHP on Hs578T cells were associated with cell cycle arrest, their cell cycle distribution was determined. The results showed that AEXHP significantly affected the cell cycle distribution of Hs578T cells, leading to cell cycle arrest at $\mathrm{S}$ phase in a 
A
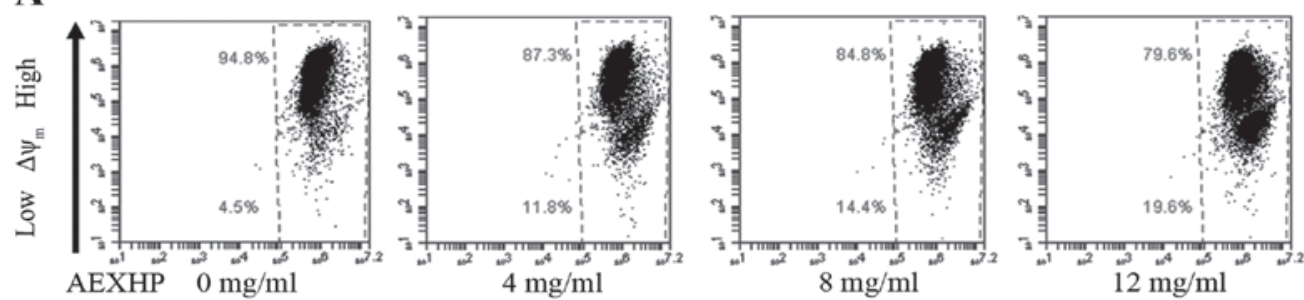

B

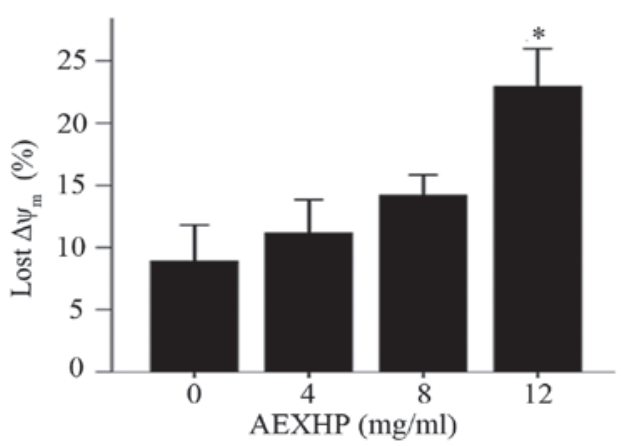

Figure 3. AEXHP induces depletion of $\Delta \psi_{\mathrm{m}}$ in Hs578T cells. Hs578T cells were treated with various concentrations of AEXHP $(0,4,8 \mathrm{or} 12 \mathrm{mg} / \mathrm{ml})$ for $24 \mathrm{~h}$ and the $\Delta \psi_{\mathrm{m}}$ was analyzed by JC-1 staining followed by flow cytometric analysis. (A) Dot plot representative of three experiments. (B) AEXHP dose-dependent induced the depletion of $\Delta \psi_{\mathrm{m}}$. Values are expressed as the mean \pm standard deviation ( $\mathrm{n}=3$ ). ${ }^{*} \mathrm{P}<0.05$ vs. control. AEXHP, aqueous extract of Xihuang pill; $\Delta \psi_{\mathrm{m}}$, mitochondrial membrane potential.

A
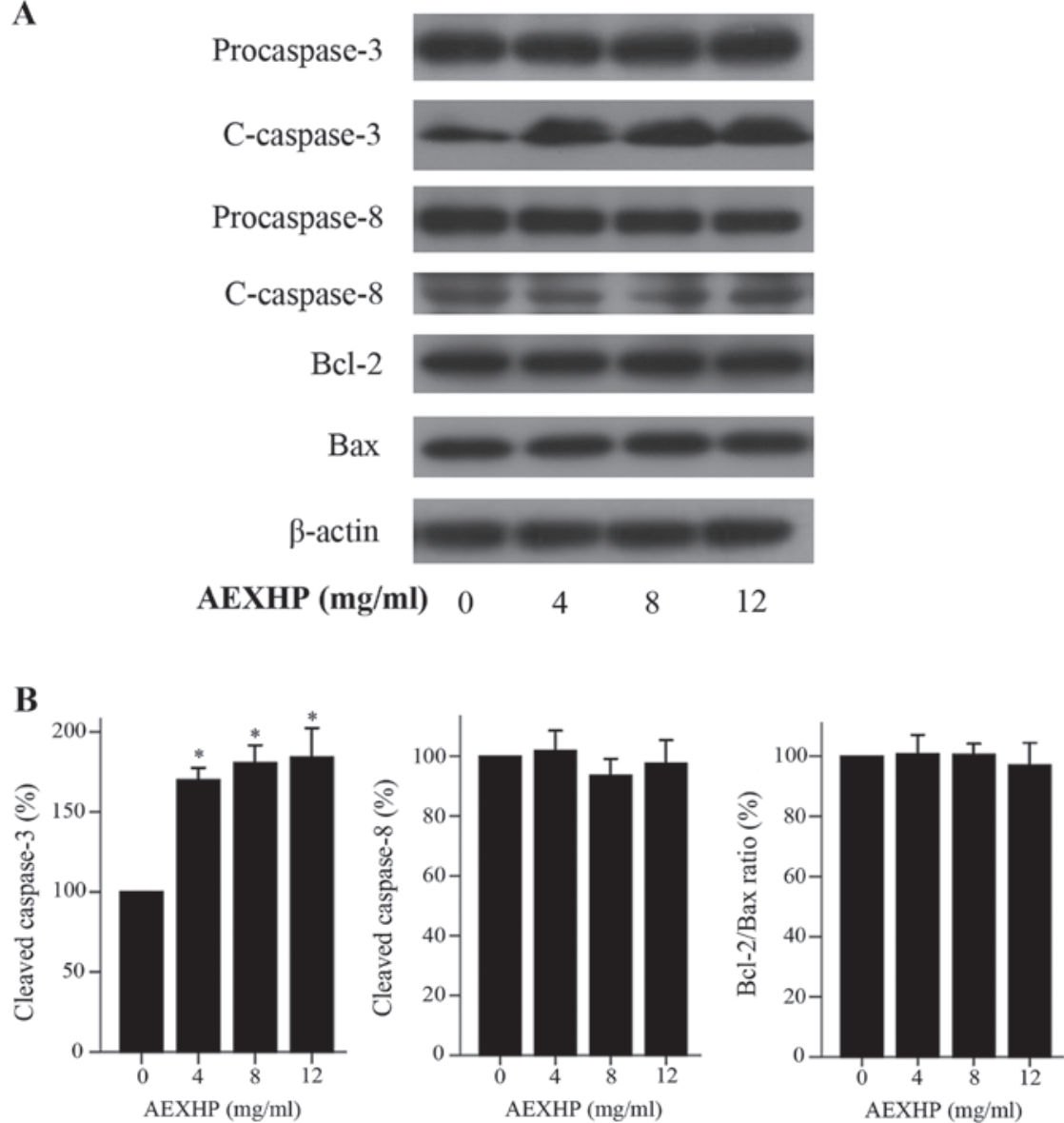

Figure 4. Assessment of apoptosis-associated proteins. Hs578T cells were treated with various concentrations of AEXHP (0, 4, 8 or $12 \mathrm{mg} / \mathrm{ml})$ for $24 \mathrm{~h}$ and subjected to western blot analysis. (A) Representative original bands of apoptosis-associated proteins are shown. Cells treated with medium $(0 \mathrm{mg} / \mathrm{ml}) \mathrm{were}$ used as control. (B) Bar graph showing that treatment with AEXHP increased the normalized protein density of cleaved caspase-3, while not affecting cleaved caspase- 8 and the density ratio of Bcl-2 to Bax in Hs578T cells. Values are expressed as the mean \pm standard deviation ( $\mathrm{n}=3$ ). ${ }^{*} \mathrm{P}<0.05$ vs. control. AEXHP, aqueous extract of Xihuang pill; C, cleaved; Bcl-2, B-cell lymphoma 2; Bax, Bcl-2-associated X protein. 

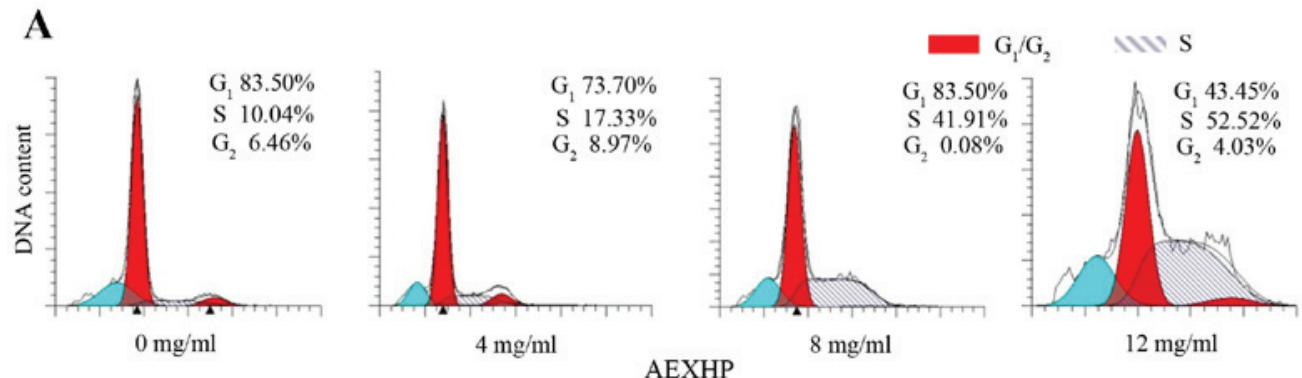

AEXHP

$12 \mathrm{mg} / \mathrm{ml}$

B

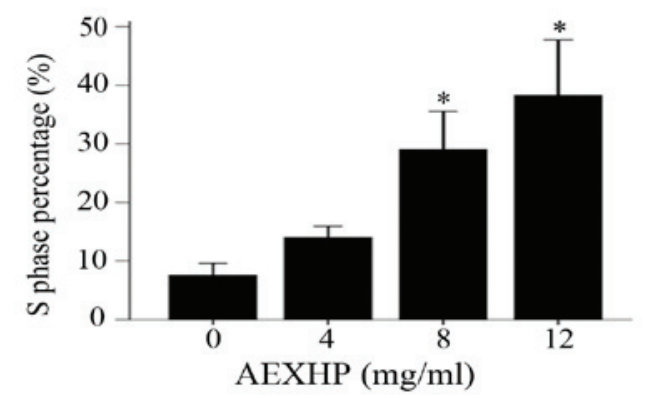

Figure 5. AEXHP causes S-phase arrest of Hs578T cells. Hs578T cells were treated with various concentrations of AEXHP (0, 4, 8 or $12 \mathrm{mg} / \mathrm{ml})$ for $48 \mathrm{~h}$ and the cell cycle distribution was determined by flow cytometry. (A) Cell cycle distributions representative of three experiments are shown. The population marked in blue is the sub- $\mathrm{G}_{1}$ population. (B) AEXHP induced cell cycle arrest at $\mathrm{S}$ phase in a dose-dependent manner. Values are expressed as the mean \pm standard deviation $(\mathrm{n}=3)$. ${ }^{*} \mathrm{P}<0.05$ vs. control. AEXHP, aqueous extract of Xihuang pill.

dose-dependent manner (Fig. 5B). While the S-phase population was $10.04 \%$ in the untreated group, treatment with 4 , 8 and $12 \mathrm{mg} / \mathrm{ml}$ AEXHP increased it to 17.33, $41.91 \quad(\mathrm{P}<0.05$ vs. control) and $52.52 \%(\mathrm{P}<0.05$ vs. control), respectively. Cell populations in $\mathrm{G}_{1}$ or $\mathrm{G}_{2} / \mathrm{M}$ phase shifted concomitantly to the changes detected in $\mathrm{S}$ phase (Fig. 5A), while there was no AEXHP dose-dependent decrease or increase in the $\mathrm{G}_{1}$ - or $\mathrm{G}_{2} / \mathrm{M}$-phase populations.

Effects of AEXHP on the expression of cell cycle regulatory proteins. To explore the mechanisms by which AEXHP induced cell cycle arrest of Hs578T cells at S phase, western blot analysis was used to determine the expression of cell cycle regulatory proteins. The results showed that treatment with various concentrations of AEXHP (4, 8 or $12 \mathrm{mg} / \mathrm{ml}$ ) for $48 \mathrm{~h}$ resulted in decreased expression of cyclin A and CDK2, as well as increased expression of cyclin E and p21 ${ }^{\mathrm{Cip} 1}$, as compared to the control group (Fig. 6A and B). The decreased expression of cyclin A and CDK2, and the increased expression of cyclin E and p21 ${ }^{\text {Cip1 }}$, may have contributed to S-phase arrest of Hs578T cells induced by AEXHP.

\section{Discussion}

As mentioned above, the aim of the present study was to assess the anti-proliferative effects of AEXHP on the Hs578T TNBC cell line, and to investigate the underlying molecular mechanisms, by performing MTT, apoptosis, cell cycle and western blot assays.

The results of the MTT assay showed that AEXHP inhibited the viability of Hs578T cells in a dose- and time-dependent manner. The difference between the cytotoxic effects of AEXHP on MCF-10A normal breast epithelial cells and Hs578T TNBCs was depended on the cell density, which was mainly due to the cell density-dependent sensitivity of the MCF-10A cells to AEXHP. When the cell density was increased from 7,500 to 10,000 cells/well, the viability of MCF-10A cells treated with $12 \mathrm{mg} / \mathrm{ml}$ AEXHP for $24 \mathrm{~h}$ increased from $43.93 \pm 9.96$ to $72.41 \pm 9.80 \%$, while that of Hs578T cells only increased marginally. The results of the present study indicated that Hs578T was equally or less sensitive to AEXHP than MCF-10A. However, due to differences in doubling times, it may be impossible to directly compare the cytotoxic effects of AEXHP on the MCF-10A normal breast epithelial cell line and Hs578T TNBCs at identical seeding density, which represents a limitation of the MTT assay performed in the present study. In fact, a previous study by our group on another TNBC cell line, MDA-MB-231, demonstrated cancer cell-specific toxicity in terms of MDA-MB-231 being more sensitive to AEXHP than the MCF-10A cell line (17). It is therefore indicated that the cytotoxic effects of AEXHP are cell type-specific, and whether they are cancer-specific warrants further investigation in a panel of cell lines.

In order to elucidate the mechanisms of the anti-proliferative activity of AEXHP, the apoptotic rate and cell cycle distribution of Hs578T treated with various concentrations of AEXHP were assessed in the present study. The results showed that AEXHP dose-dependently decreased the viability of Hs578T cells, and simultaneously induced apoptosis and S-phase arrest. In order to investigate via which pathways AEXHP induces apoptosis in Hs578T, the protein expression of caspase- 8 and caspase- 3 were detected by western blot analysis. While procaspase-3 was not significantly affected, the levels of cleaved caspase-3 were significantly increased following AEXHP treatment. However, the protein levels of procaspase- 8 and cleaved caspase- 8 were not affected, leading to the conclusion that AEXHP induces apoptosis via the intrinsic, but not the extrinsic pathway. 
A
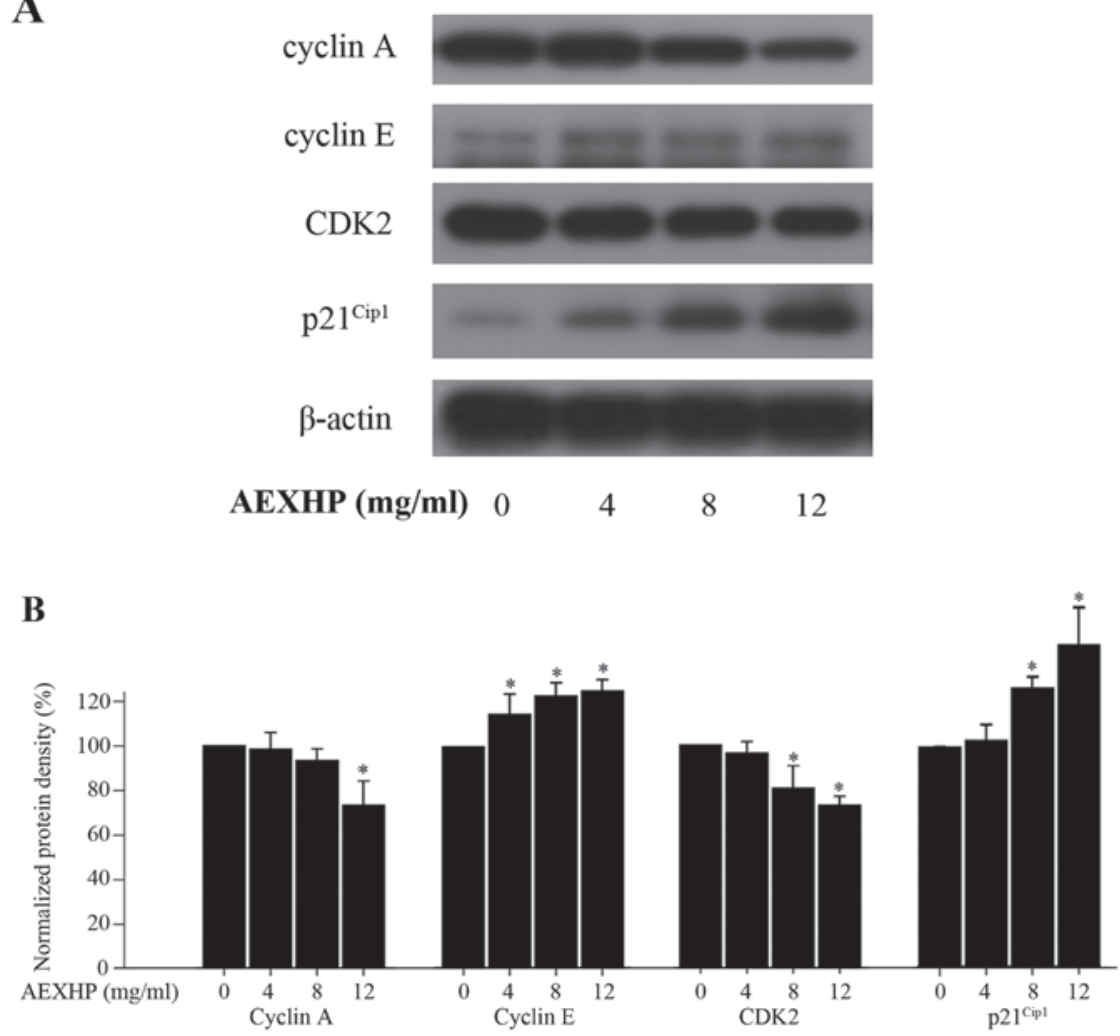

Figure 6. AEXHP affects the expression of cell cycle regulatory proteins in Hs578T cells. Cells were treated with various concentrations of AEXHP (0, 4 , 8 or $12 \mathrm{mg} / \mathrm{ml}$ ) for $48 \mathrm{~h}$, followed by western blot analysis of cell cycle regulatory proteins. (A) Representative original bands of each apoptosis-associated proteins are shown. Cells treated with medium $(0 \mathrm{mg} / \mathrm{ml})$ were used as a control. (B) Bar graph showing that treatment with AEXHP dose-dependently decreased the normalized protein density of cyclin A and CDK2, while increasing cyclin E and $\mathrm{p} 21^{\mathrm{Cip} 1}$. Values are expressed as the mean \pm standard deviation $(\mathrm{n}=3) .{ }^{*} \mathrm{P}<0.05$ vs. control. AEXHP, aqueous extract of Xihuang pill; CDK, cyclin dependent kinase.

Bax constitutes the ion channel of the mitochondrial membrane in human cells, while Bcl-2 combines with Bax to inhibit it, with the $\mathrm{Bcl}-2 / \mathrm{Bax}$ ratio therefore having a decisive role in the induction of apoptosis (18). In the present study, western blot analysis showed that $\mathrm{Bax}, \mathrm{Bcl}-2$ and the $\mathrm{Bcl}-2 / \mathrm{Bax}$ ratio were not affected by AEXHP, leading to the conclusion that the depletion of the $\Delta \psi_{\mathrm{m}}$ induced by AEXHP was not associated with the $\mathrm{Bcl}-2 / \mathrm{Bax}$ ratio, and was therefore likely to be linked with factors directly destroying the mitochondrial membrane, which requires to be further elucidated.

Cell cycle progression is orchestrated by a complex network of interactions between proteins, including cyclins, CDKs, E3 ubiquitin ligase complexes, CDK activating kinase, CDC25 phosphatases and CDK inhibitors (19). To explore the mechanisms by which AEXHP induces cell cycle arrest in Hs578T cells at $\mathrm{S}$ phase, western blot analysis was used to assess the modulation of the expression of cell cycle regulatory proteins by AEXHP. The results showed that AEXHP treatment resulted in decreased expression of cyclin A and CDK2, and increased expression of cyclin $\mathrm{E}$ and $\mathrm{p} 21^{\mathrm{Cip} 1}$, which explains for the S-phase arrest observed. Cyclin A and CDK2 are specific S-phase regulatory proteins (19), and the increased cyclin E enhances $\mathrm{G}_{1}$-to-S-phase progression. $\mathrm{p} 21^{\text {Cipl }}$ not only forms complexes with cyclin D-, cyclin E- or cyclin A-dependent kinase and inhibits their activities, but also binds to and inhibits proliferating cell nuclear antigen to curb the synthesis of DNA (20), which is the main task during $\mathrm{S}$ phase. In addition, the expression of cyclin B and CDK1 were assessed in the present study (data not shown). The expression of these two proteins was not significantly affected by AEXHP, which is in line with the observed S-phase arrest, as cyclin B and $\mathrm{CDK} 1 \mathrm{G}_{2} / \mathrm{M}$ phase-specific cell cycle regulatory proteins. The limitation of the present study was that the effects of AEXHP were only assessed on one TNBC cell line, Hs578T, in vitro. However, in a previous study by our group, a xenograft tumor model using another TNBC cell line, MDA-MB-231, was established, which proved the anti-tumor effects of AEXHP in vivo (results not shown). Another limitation of the present study was that the active components in the AEXHP may be different from those in the serum of patients taking XHP for the treatment of cancer. Furthermore, the cytotoxic effects of AEXHP on the Hs578T cell line may not be equivalent to those of XHP in TNBC patients. Further studies in the clinical setting are required to confirm the antitumor effects of XHP on TNBC. Furthermore, the active components of AEXHP should be isolated and their structure should be identified in future studies.

In conclusion, the present study revealed that AEXHP significantly inhibited the viability of Hs578T cells in vitro in a dose- and time-dependent manner. The possible underlying mechanisms include induction of apoptosis and cell cycle arrest at $\mathrm{S}$ phase. AEXHP was indicated to induce apoptosis in Hs578T cells via the intrinsic, Bcl-2/Bax-independent pathway. $\mathrm{S}$-phase arrest was likely to be due to the combined effects of decreased expression of cyclin A and CDK2 as well as increased expression of cyclin E and p21 ${ }^{\mathrm{Cip} 1}$. The present study 
therefore indicated that AEXHP is potent against the Hs578T TNBC cell line, providing in vitro evidence to support the clinical use of XHP as a prescription for TNBC.

\section{Acknowledgements}

The present study was supported by the key program foundation of Beijing Administration of Traditional Chinese Medicines (no. 2004-IV15).

\section{References}

1. Liedtke C, Bernemann C, Kiesel L and Rody A: Genomic profiling in triple-negative breast cancer. Breast Care (Basel) 8 : 408-413, 2013

2. Bosch A, Eroles P, Zaragoza R, Viña JR and Lluch A: Triple-negative breast cancer: Molecular features, pathogenesis, treatment and current lines of research. Cancer Treat Rev 36 206-215, 2010

3. Yadav BS, Sharma SC, Chanana P and Jhamb S: Systemic treatment strategies for triple-negative breast cancer. World J Clin Oncol 5: 125-133, 2014

4. Jiao Q, Wu A, Shao G, Peng H, Wang M, Ji S, Liu P and Zhang J: The latest progress in research on triple negative breast cancer (TNBC): Risk factors, possible therapeutic targets and prognostic markers. J Thorac Dis 6: 1329-1335, 2014.

5. Meng Z, Garrett CR, Shen Y, Liu L, Yang P, Huo Y, Zhao Q, Spelman AR, Ng CS, Chang DZ, et al: Prospective randomised evaluation of traditional Chinese medicine combined with chemotherapy: A randomised phase II study of wild toad extract plus gemcitabine in patients with advanced pancreatic adenocarcinomas. Br J Cancer 107: 411-416, 2012.

6. Guo Q, Lin J, Liu R, Gao Y, He S, Xu X, Hua B, Li C, Hou W, Zheng $\mathrm{H}$ and Bao Y: Review on the applications and molecular mechanisms of Xihuang pill in tumor treatment. Evid Based Complement Alternat Med 2015: 854307, 2015.

7. Jin SR, Zhu BD and Qin XH: Comparative study of anti-tumors effects of Xi Huang Pellet by Different Processing Methods. Shi Zhen Guo Yi Guo Yao 19: 1735-1737, 2008.
8. Pan G, Wang W, Wang L, Zhang F, Yin X, Wang J and Liang R: Anti-breast cancer effects and mechanisms of Xihuang pill on human breast cancer cell lines. J Tradit Chin Med 33: 770-778, 2013.

9. Wang W, Li N, Luo M and Zu Y and Efferth T: Antibacterial activity and anticancer activity of Rosmarinus officinalis L. essential oil compared to that of its main components. Molecules 17: 2704-2713, 2012.

10. Fulda S and Debatin KM: Extrinsic versus intrinsic apoptosis pathways in anticancer chemotherapy. Oncogene 25: 4798-4811, 2006.

11. Budihardjo I, Oliver H,Lutter M, Luo X and Wang X: Biochemical pathways of caspase activation during apoptosis. Annu Rev Cell Dev Biol 15: 269-290, 1999.

12. Nicholson DW: Caspase structure, proteolytic substrates, and function during apoptotic cell death. Cell Death Differ 6: 1028-1042, 1999.

13. Strasser A, Huang DCS and Vaux DL: The role of the bcl-2/ced-9 gene family in cancer and general implications of defects in cell death control for tumourigenesis and resistance to chemotherapy. Biochim Biophys Acta 1333: F151-F178, 1997.

14. Gao N, Budhraja A, Cheng S, Yao H, Zhang Z and Shi X: Induction of apoptosis in human leukemia cells by grape seed extract occurs via activation of c-Jun NH2-terminal kinase. Clin Cancer Res 15: 140-149, 2009.

15. Shapiro GI and Harper JW: Anticancer drug targets: Cell cycle and checkpoint control. J Clin Invest 104: 1645-1653, 1999.

16. Choi EJ, Oh HM, Wee H, Choi CS, Choi SC, Kim KH, Han WC, Oh TY, Kim SH and Jun CD: Eupatilin exhibits a novel anti-tumor activity through the induction of cell cycle arrest and differentiation of gastric carcinoma AGS cells. Differentiation 77: 412-423, 2009.

17. Zheng W, Han S, Jiang S, He X, Li X, Ding H, Cao M and Li P. The multi-effect of Xihuang Pill on MDA-MB-231 cell lines in vitro and in vivo. Mol Med Rep (In press).

18. Wong RS: Apoptosis in cancer: From pathogenesis to treatment. J Exp Clin Cancer Res 30: 87, 2011.

19. Diaz-Moralli S, Tarrado-Castellarnau M, Miranda A and Cascante M: Targeting cell cycle regulation in cancer therapy. Pharmacol Ther 138: 255-271, 2013.

20. Sherr CJ and Roberts JM: CDK inhibitors: Positive and negative regulators of G1-phase progression. Genes Dev 13: 1501-1512, 1999. 